\title{
Response of Eucalyptus grandis in Colombia to mid-rotation fertilization is dependent on site and rate but not frequency of application
}

4 Timothy J. Albaugh ${ }^{1 *}$, Rafael A. Rubilar ${ }^{2}$, Thomas R. Fox ${ }^{1}$, H. Lee Allen ${ }^{3}$, John B. Urrego ${ }^{4}$, Marcela 5 Zapata $^{4}$, and Jose L. Stape ${ }^{5}$

$6{ }^{1}$ Virginia Tech Department of Forest Resources and Environmental Conservation, 228 Cheatham Hall, 7 Blacksburg, VA 24061, email: Tim Albaugh@vt.edu, trfox@vt.edu

${ }^{2}$ Cooperativa de Productividad Forestal. Facultad de Ciencias Forestales, Universidad de Concepción. Victoria 631, Casilla 160-C, Concepción, Chile. Phone: 56-41-2204980 email: rafaelrubilar@udec.cl

${ }^{3}$ ProFor Consulting, Cary, NC, email: allen.profor@gmail.com

${ }^{4}$ Smurfit Cartón de Colombia, AA219 Cali, Colombia, email: john.urrego@smurfitkappa.com.co, marcela.zapata@smurfitkappa.com.co

${ }^{5}$ Department of Forestry and Environmental Resources, North Carolina State University, Raleigh, NC 27695-8008. NCSU, Raleigh, NC 27695-8008, email: jlstape@ncsu.edu

* Corresponding author 

$41 \mathrm{ha}^{-1}$.

\section{ABSTRACT}

A nutrient dose and application frequency study was installed in Eucalyptus grandis stands at six sites in the Colombian Andes to examine three hypotheses: 1) individual sites have different treatment responses (there is a significant site effect); 2) the relationship between volume growth response and applied nitrogen is not linear (there is an optimal amount of applied nitrogen beyond which growth improvements would be small); and 3) application frequency does not affect response if the cumulative dose applied is equivalent (there is no frequency effect). Nitrogen, phosphorus and boron were applied at a 1.0: 0.1: 0.005 ratio, where nitrogen rates ranged from 0 to $250 \mathrm{~kg} \mathrm{ha}^{-1}$ and application frequency was $6,12,24$ or 36 months. Fertilization began when trees were 11 to 24 months old and we examined volume growth response three years after study initiation when the maximum cumulative nitrogen application reached $720 \mathrm{~kg} \mathrm{ha}{ }^{-1}$. There was a significant site effect: two sites were responsive and four were non-responsive to treatment. At the two responsive sites, the relationship between volume growth response and applied nitrogen was not linear. Three years after treatment initiation, the maximum absolute response was 142 $\mathrm{m}^{3} \mathrm{ha}^{-1}$ (91\% increase) and $116 \mathrm{~m}^{3} \mathrm{ha}^{-1}$ (56\% increase) for Sites 1 and 4, respectively. Sites 1 and 4 reached maximum volume response at cumulative nitrogen doses of 360 and $480 \mathrm{~kg} \mathrm{ha}^{-1}$, respectively. Tests that compared different nitrogen application rates and frequencies to achieve the same cumulative dose were not significantly different except for one test at Site 4 where the volume growth response to three applications of $180 \mathrm{~kg}$ nitrogen $\mathrm{ha}^{-1}$ was $58 \%$ greater than the response to six applications of $90 \mathrm{~kg}$ 
Introduction

Plantation productivity can be predicted from the availability and use of site resources that are conditioned by environmental constraints (Stape et al., 2008). Good weed control and adequate fertilization increase water and nutrient availability. Consequently, these silvicultural treatments are needed for good survival and high initial growth rates of Eucalyptus plantations (Adams et al., 2003; In second rotation stands, the response to nutrients applied soon after establishment may be limited by adequate resource availability from mineralization of extant organic matter (the assart effect, (Kimmins rapid crown closure to achieve full site occupancy; nutrients play a role in stimulating leaf area increased the mean annual increment of Eucalyptus grandis by $28 \mathrm{~m}^{3} \mathrm{ha}^{-1}$ year ${ }^{-1}$. While the observed gains in this study are impressive, the biological potential of the site-species combination may not have been achieved given other work in Eucalyptus where reported growth rates exceed $80 \mathrm{~m}^{3} \mathrm{ha}^{-1}$ year $^{-1}$ (Stape et al., 2004).

Fertilizer responses are variable in stands that have reached canopy closure. Eucalyptus plantations exhibit fertilizer growth responses at sites with inherent nutritional deficiencies (Bennett et al., 1997; Campion et al., 2006; Cromer et al., 1993; Herbert 1983; Schonau 1983; Schonau and Herbert 1989). In one study where fertilizer was applied three times per year for the first six years, E. grandis volume decreased by $12 \mathrm{~m}^{3} \mathrm{ha}^{-1}$ in the first year; however, by age nine, productivity had doubled in the fertilized plots (Birk and Turner 1992). Birk and Turner (1992) hypothesized that the lack of early response to fertilization was due to adequate soil fertility or that other species successfully competed for the added nutrients. However, fertilization in years 2 through 6 clearly had a large positive impact in this study. Similarly, sites where nutrient availability was reduced as a result of detrimental effects of past silvicultural treatments, including harvest intensity, would likely respond to fertilization applied after canopy closure (Judd 1996; Turner and Lambert 1996). 
Conversely, other studies have shown no growth improvement to fertilization application after canopy closure on sites with high fertility levels or those prone to long water deficits (Dye 1996; Little and Rolando 2002; Miller 1981; Myers et al., 1996). For example, a nutrition by irrigation study in three-yearold E. grandis $x$ urophylla clones in a fertile region of Brazil showed no response to fertilization (Stape et al., 2008). A similar study examining clonal Eucalyptus growth potential across eight sites in Brazil did not show differences between fertilizer applied at planting and fertilizer applied three times annually for the first three years (Stape et al., 2010). In South Africa, four experiments with E. grandis had no response to fertilizer when fertilized with nitrogen, phosphorus, potassium, and lime eighteen months after planting (Schonau 1983). Mechanisms to explain this lack of response to nutrient additions after canopy closure include high native site fertility (Stape et al., 2010), other resources (water) are primarily limiting (Campion et al., 2006), the nutrients that become available through mineralization or slash and litterfall decomposition are sufficient to meet plant demand (Goncalves et al., 2004; Nzila et al., 2004), and heartwood development, which can begin by age three in E. grandis, results in available nutrients from internal biochemical cycling (Da Silva et al., 2001). Another possibility is continued nutrient availability from early rotation applications that provide nutrients throughout the rotation (Smethurst et al., 2003).

Consequently, after canopy closure, fertilizer responses are dependent on a range of factors and this situation makes it difficult to determine which sites will be responsive. In addition, sites that do respond to fertilizer may not achieve the biological potential of the site because they could still be resource (nutrients or other resources) limited. For example, Smethurst et al. (2003) found that some sites that responded to fertilizer treatments at young ages also responded to additional fertilizer applied at later ages. In the literature, fertilizer application rates range from those applied to eliminate all nutrient limitation (many elements applied) (Stape et al., 2008) to those where a combination of relatively high rates of nitrogen and phosphorus were applied (1600 and $700 \mathrm{~kg} \mathrm{ha}^{-1}$ for nitrogen and phosphorus, respectively) (Smethurst et al., 2003). No studies were found where the same total nutrient dose was achieved using different rates and frequencies of application.

There are 405,000 ha of planted forest in Colombia, of which approximately $19 \%$ are in $E$. globulus and E. grandis (FAO 2010; FAO 2015). However, only about $60 \%$ of domestic demand is met 
from plantations, and there is pressure on the native forest such that the Colombian government is promoting the establishment of new plantations to reduce this pressure (Boyd 1998; FAO 2015). Another way to reduce the pressure on native forests is to increase the productivity of existing plantations with fertilization to help meet these demands. However, no information was found in the literature regarding mid-rotation fertilizer effects or productive potential for $E$. grandis plantations in Colombia. Given evidence for the assart effect in E. grandis stands (Goncalves et al., 2004; Nzila et al., 2004), our interest was in examining the response to nutrient applications after crown closure when the assart effect diminishes and stands may become nutrient limiting. These factors led us to investigate the response of E. grandis growing in the Colombian Andes to fertilization where both the rate and frequency of fertilization were varied. By altering the dose and frequency of application, we could determine if stands were responsive to fertilizer and, if they were responsive, at what point the response leveled off and no additional response was achieved. We examined these hypotheses: 1) individual sites have different treatment responses (there is a significant site effect); 2) the relationship between volume growth response and applied nitrogen is not linear (there is an optimal amount of applied nitrogen beyond which growth improvements would be small); and 3) application frequency does not affect response if the cumulative applied dose is equivalent (there is no frequency effect).

\section{Methods}

Six sites planted with Eucalyptus grandis were selected to represent a range of soil-site conditions in the Colombian Andes (Table 1). The selected sites were representative of Quindio and of Valle, Lomajes and Meseta in the Cauca River Basin. The range in altitude was 1690 to $2127 \mathrm{~m}$ asl. Soils were loamy, well drained Andisols. Previous land use was pasture (Sites 1) or plantation (Sites 2-6); the plantation sites received fertilization at planting similar to that which was applied for the current rotation and is mentioned below. Information about prior fertilization of the pasture site was not available. Site index ranged from 22 to $28 \mathrm{~m}$ (base age 7 years). Site preparation for all sites was chemical preparation with glyphosate followed by tillage $(30 \times 30 \times 30 \mathrm{~cm})$ at each planting spot and residues were left in place to decompose. Each site was fertilized at planting with $12 \mathrm{~g}$ nitrogen, $13 \mathrm{~g}$ phosphorus, $8 \mathrm{~g}$ potassium and $10 \mathrm{~g}$ boron plant $^{-1}$, and received at least two weed control operations (mechanical and chemical (glyphosate)) during the first year of growth. Stand age at treatment initiation ranged from 11 to 
24 months. Prior to treatment initiation, stocking across all sites ranged from 959 to 1280 trees $^{-1}$, diameter at breast height ranged from 3.3 to $9.5 \mathrm{~cm}$, basal area ranged from 0.8 to $8.4 \mathrm{~m}^{2} \mathrm{ha}^{-1}$ and stem volume ranged from 12 to $67 \mathrm{~m}^{3} \mathrm{ha}^{-1}$ (Table 2).

\section{Experimental Design}

We installed a randomized complete block design with three or four replications at each site. Sites were blocked on height, basal area and stocking prior to treatment initiation to ensure homogeneity. Plots within a block had less than $10 \%$ difference for these variables. Measurement plots varied in size from 0.021 to 0.039 ha ( 0.032 ha average) and were surrounded by a $15-\mathrm{m}$ treated buffer such that the average treated plot size was 0.189 ha. Treatments were a combination of application frequency and nutrient (nitrogen, phosphorus and boron) dose (Table 3). Application frequency was every six, 12, 24 or 36 months. All nutrient applications mentioned in this document are elemental rates. Nitrogen was applied at $0,60,75,90,120,150,180,240$ or $250 \mathrm{~kg}$ nitrogen $\mathrm{ha}^{-1}$. Phosphorus and boron were added with nitrogen at values of 0.1 and 0.005 times the nitrogen rate. The nitrogen:phosphorus ratio was selected based on the estimated 10:1 nitrogen:phosphorus ratio found in many plants (Knecht and Göransson 2004; Linder 1995). Boron was added because boron is known to be limiting in these soils (Shorrocks 1997) and boron deficiencies have been induced by macronutrient fertilizer applications (Stone 1990). There is a narrow range between adequate and toxic levels of boron (Dell and Malajczuk 1994; Stone 1990); consequently, we added boron at 0.005 times the nitrogen rate to insure that sufficient boron would be available and that potentially toxic levels would not be generated with high nitrogen doses applied in some treatments. Subsequent references to treatment indicate only applied nitrogen for brevity in presentation; however, as noted here, nitrogen, phosphorus and boron were applied. The nutrients were added as urea, diammonium phosphate and borax. Urea applications may be susceptible to urea volatilization (Zerpa and Fox 2011). An additional benefit of adding boron is that it acts to reduce urea volatilization (Whitehurst and Whitehurst 2004). Furthermore, the fertilizer applications were completed under conditions that reduce the risk of volatilization (low temperature and humidity with the expectation of heavy rainfall within $24-48$ hours after application).

The application frequencies and nutrient doses were selected to span a range of nutrient applications such that the same total dose at a given time would be achieved from different combinations 
of nutrient dose and application frequency. For example, applying $120 \mathrm{~kg}$ nitrogen ha ${ }^{-1}$ every six months for three years resulted in a cumulative dose of $720 \mathrm{~kg}$ nitrogen $\mathrm{ha}^{-1}$. This same cumulative dose was also achieved with the annual application of $240 \mathrm{~kg}$ nitrogen ha ${ }^{-1}$ over three years. Different doses and application frequencies were used at each site; however, the control (no nutrients added), $120 \mathrm{~kg}$ nitrogen $\mathrm{ha}^{-1}$ applied every year and $240 \mathrm{~kg}$ nitrogen $\mathrm{ha}^{-1}$ applied every two years were implemented at all sites (Table 3).

Foliage samples were collected from five dominant or co-dominant trees in each plot prior to treatment initiation at all sites and every six months thereafter for Sites 1, 2, 3, and 4. Available resources did not permit foliage sampling and nutrient analysis after treatment initiation at Sites 5 and 6. Foliage was collected in the upper one-third of the live crown and foliar samples were dried at $65{ }^{\circ} \mathrm{C}$ to a constant weight. Samples were composited by plot and analyzed using a CHN analyzer (CE Instruments NC2100 elemental analyzer) for nitrogen (CE Instruments, 1997) and a nitric acid digest and ICP (Varian Liberty II ICO-AES) analysis was used for the other elements (Huang and Schulte 1985). Duplicate samples and standard samples from the laboratory and the United States National Bureau of Standards were included with all analytic runs to ensure data quality. Soil pH was measured in water. Soil was analyzed using the Semimicro-Kjeldhal method for nitrogen (Hitchcock and Belden 1933), the WalkleyBlack method for organic matter (Walkley 1947), the Bray II method for phosphorus (Bray and Kurtz 1945), extracted with ammonium acetate and analyzed using an atomic absorption spectrophotometer for potassium, calcium and magnesium, and extracted following the Yuan method and analyzed using an atomic absorption spectrophotometer for aluminum (Yuan and Fiskell 1959).

Diameter at breast height $(1.3 \mathrm{~m})$ and tree height were measured prior to treatment initiation and every six months thereafter. Individual tree volume was calculated from diameter at breast height using a proprietary function developed by Smurfit Cartón de Colombia. Individual tree volume and basal area were summed by plot and scaled to a hectare basis. The treatment response at a given time period was calculated as the mean of the treatment growth minus the control growth for all blocks at a site. The relative treatment response was the treatment response divided by the control growth.

\section{Statistical Analyses}


PROC MIXED (SAS Institute, 2002) was used to examine the treatment effects three years after treatment initiation for diameter, height, basal area, volume and survival. Survival data were arc sine transformed for statistical analysis. Site effects were examined, where fixed effects were site, treatment and their interaction, and random effects were block within site. Within site treatment effects used treatment as the fixed effect and block as the random effect. Tukey-Kramer means tests were used to determine the treatment differences for the three year growth data at each site. Linear and quadratic effects were tested to determine whether fertilizer rate affected response. Contrasts tested treatments at each site that resulted in the same cumulative rate achieved from different frequencies. Foliar nutrient concentrations were examined by site and element using repeated measures analysis with PROC MIXED. Block was treated as a random variable. Tukey-Kramer means test were used to determine differences in treatment means for a given measurement date. If more than three dates for a site-element combination had significant differences between treatment means, the data for that element, site and set of treatments were graphed. All statistical tests were evaluated with alpha equal to 0.05 .

\section{Results}

Initial foliar nitrogen concentrations ranged from 1.73 to $2.34 \%$ (Table 4). Control treatment foliar nutrient concentrations varied significantly through time (significant time since treatment initiation effect) for all sites and all elements except for phosphorus at Site 1 (Tables 4 and 5). Treatment effects and treatment by time effects were significant for nitrogen and phosphorus at Site 4 such that the control treatment was lower than all treatments, and significant means comparisons were observed at 18,30 and 36 months since treatment initiation (Table 5 and Figure 1A and 1B). Treatment effects and treatment by time effects were significant for boron at Site 3 such that the control treatment was lower than all treatments and significant means comparisons were observed at 24, 30 and 36 months since treatment initiation (Table 5 and Figure 1C). Other significant treatment means were observed at Site 1 for calcium at 12 months where the 224 treatment was less than the control, Site 2 for magnesium at 36 months where the control treatment was greater than the 124, 224 and 506 treatments, and Site 4 for sulfur (at 18 months the control was less than the 509 treatment), zinc (at 12 months the control was less than the 224 treatment), and copper (at 36 months, treatment 118 was less than the 218 and 506 treatments). 
Three years after treatment initiation, site effects were significant (at least $p<0.002$ ) for all growth measurements (diameter, height, basal area, volume and survival); consequently, the studies were examined individually.

Three years after treatment initiation, Sites 1 and 4 exhibited significant treatment effects for diameter, height, basal area and volume growth (Tables 6a and 6b). Means comparisons for Sites 1 and 2144 indicated that the control was typically less than most or all of the other treatments. Absolute responses 215 for the other four sites $(2,3,5$, and 6$)$ were both positive and negative (greater than or less than the 216 control); however, these effects were not statistically significant and means comparisons indicated that none of the means were significantly different for any variable measured. Treatments $124(240 \mathrm{~kg}$ 218 nitrogen ha ${ }^{-1}$ applied every year) and 118 (180 kg nitrogen ha ${ }^{-1}$ applied every year) had the greatest absolute responses at Sites 1 and 4, respectively. At Site 1, treatment 124 increased diameter $(3.6 \mathrm{~cm}$, $30 \%)$, height $(4.7 \mathrm{~m}, 29 \%)$, basal area $\left(9.3 \mathrm{~m}^{2} \mathrm{ha}^{-1}, 60 \%\right)$ and volume $\left(142 \mathrm{~m}^{3} \mathrm{ha}^{-1}, 91 \%\right)$. At Site 4 , treatment 118 increased diameter $(2.1 \mathrm{~cm}, 14 \%)$, height $(3.3 \mathrm{~m}, 15 \%)$, basal area $\left(7.9 \mathrm{~m}^{2} \mathrm{ha}^{-1}, 38 \%\right)$ and volume (116 $\left.\mathrm{m}^{3} \mathrm{ha}^{-1}, 100 \%\right)$. Survival was not influenced by treatment at any site (Tables $6 \mathrm{a}$ and $6 \mathrm{~b}$ ) and 223 averaged $97 \%$ across all sites and treatments.

Three years after treatment initiation, significant linear and quadratic effects were observed at 225 Sites 1 and 4, indicating that response was affected by rate (Table 7 and Figure 2). At Site 1, linear 226 effects were found for diameter, height, basal area and volume responses, and quadratic effects were found for diameter and basal area. At Site 4, linear and quadratic effects were found for diameter, height, basal area and volume responses. None of the other sites $(2,3,5$, and 6$)$ had significant linear or 229 quadratic rate effects on growth response. At Sites 1 and 4 , volume response continued to increase until a dose of 480 and $360 \mathrm{~kg}$ nitrogen $\mathrm{ha}^{-1}$, respectively, was applied (Figure 2). Survival was not influenced by rate at any of the sites.

Three years after treatment initiation, only one of the eleven tests comparing application 233 frequency to achieve the same cumulative dose was significant (Table 8 and Figure 3). The significant 234 test was at Site 4 where a cumulative dose of $540 \mathrm{~kg}$ nitrogen ha ${ }^{-1}$ (achieved in three applications of 180 235 $\mathrm{kg}$ nitrogen ha-1) increased volume growth response by $38 \mathrm{~m}^{3} \mathrm{ha}^{-1}$, whereas the same dose achieved with 236 six applications of $90 \mathrm{~kg}$ nitrogen ha ${ }^{-1}$ increased volume growth response by $24 \mathrm{~m}^{3} \mathrm{ha}^{-1}$. 


\section{Discussion}

We accepted our first hypothesis because site was a significant factor in the analyses. Sites 1 and 4 were responsive to treatment but none of the other sites were. Both of the responsive sites had relatively low pre-treatment foliar nitrogen concentrations $(1.90 \%$ and $1.81 \%$ nitrogen for Sites 1 and 4 , respectively) (Table 4).

We accepted our second hypothesis at Site 4 but not at Site 1. At Site 4, there was a significant quadratic effect for volume growth (Table 7) and there was a significant quadratic effect for diameter, height and basal area growth. When the applied nitrogen dose exceeded $480 \mathrm{~kg} \mathrm{ha}^{-1}$, no additional growth response was observed (Figure 2). At Site 1, there were significant quadratic responses for diameter and basal area but not for height or volume. However, had we selected a less strict significance level (0.10 instead of 0.05$)$, volume and height would have shown significant quadratic effects and no additional volume growth would be expected above a nitrogen dose of $360 \mathrm{~kg} \mathrm{ha}^{-1}$. A linear response function implies that response continues to increase regardless of the amount of resource applied, i.e., in contrast to a quadratic response, the treatment level where no additional response occurs has not been applied in the case where a linear response is observed. For example, Whitesell et al. (1992) report data where biomass production continued to increase linearly as nitrogen was applied from 0 to $450 \mathrm{~kg} \mathrm{ha}^{-1}$. Consequently, we do not know the maximum response possible for their species-site combination. Our study was designed to apply sufficient nutrients (up to $720 \mathrm{~kg} \mathrm{ha}^{-1}$ of applied nitrogen) such that the response would no longer be linear because an asymptote would be reached, resulting in a significant quadratic effect. The sites with a significant quadratic effect followed Liebig's Law of the Minimum where some factor (e.g., water, other nutrients, space) other than that being applied became limiting.

We accepted our third hypothesis at Sites 1, 2, 3, 5 and 6 but not at Site 4 for all treatment comparisons. For example, at Site 1 , a cumulative dose of $360 \mathrm{~kg}$ nitrogen ha ${ }^{-1}$ was achieved in three applications of $120 \mathrm{~kg}$ nitrogen ha ${ }^{-1}$ or six applications of $60 \mathrm{~kg}$ nitrogen ha-1. In addition, a cumulative dose of $720 \mathrm{~kg}$ nitrogen ha ${ }^{-1}$ was achieved in three applications of $240 \mathrm{~kg}$ nitrogen ha ${ }^{-1}$ or six applications of $120 \mathrm{~kg}$ nitrogen ha- ${ }^{-1}$. In both of these cases, there was no difference between the effect of three large doses and six smaller doses of nitrogen on the three-year volume response (Table 8 and Figure 3). At Site 4, one comparison followed this pattern; however, when $540 \mathrm{~kg}$ nitrogen ha ${ }^{-1}$ was applied as three 
and six doses of 180 and $90 \mathrm{~kg}$ nitrogen ha ${ }^{-1}$, respectively, there was a significant difference in the threeyear volume response for these treatments. The three dose application yielded a response of $38 \mathrm{~m}^{3} \mathrm{ha}^{-1}$ $\mathrm{yr}^{-1}$, i.e., $58 \%$ greater than the volume response when the dose was applied in six doses. It is unlikely that the low dose $\left(90 \mathrm{~kg} \mathrm{ha}^{-1}\right.$ per application) did not allow the trees to overcome their limitation or that volatilization was a factor in reducing the effective dose given that we applied a lower dose $\left(60 \mathrm{~kg} \mathrm{ha}^{-1}\right.$ per application) in the 506 treatment that responded to treatment and grew as well as the 112 and 218 treatments in the other comparison at this site. We selected uniform sites with little competing vegetation, maintained good vegetation control throughout the study, selected plots that were uniform with regards to tree size and stocking prior to treatment, and used large buffers between plots that would exclude cross contamination of treatments. Care was taken when applying fertilizers throughout the study to ensure that the proper dose was applied and to apply the fertilizer under conditions that would minimize volatilization. Survival at the end of the study was $100 \%$ in both of these treatments (i.e., the three and six dose applications at Site 4). These conditions make it difficult to determine why this comparison indicated a significant difference. One possibility is the selected plots were similar at the time of installation but other site factors, such as effective rooting depth, differed across the site such that later in the rotation, this factor adversely affected the response differentially across the site.

Considerable work has been completed in measuring Eucalyptus foliar nutrient concentrations; one review compiled data from over 500 references (Judd et al., 1996). Interestingly, while most data from our study were within the reported ranges for $E$. grandis in that review, the magnesium concentrations measured at Sites 1,2 and 3 fell below the range, and boron concentrations were above (Sites 1, 2, 3, 4, and 6) and below (Sites 1 and 3) the reported range (Table 4). Few references make recommendations regarding optimum nutrient concentrations for E. grandis plantations (Herbert 1996; Schonau 1983), whereas a greater emphasis has been placed on identifying optimum nutrient ratios (Judd et al., 1996). At the same time, few critical concentrations (i.e., the concentration associated with $90 \%$ of maximum productivity) have been determined, in part because of the difficulty in measuring and then verifying these values in the field (Dell 1996). Initially, all sites in this study were below the most conservative optimum values for phosphorus $(0.15 \%)$ and magnesium $(0.30 \%)$. Additionally, all sites except Site 4 were below the optimum value for boron, Site 4 was below the optimum for nitrogen $(2.0 \%)$, 
potassium $(0.70 \%)$ and calcium (1.0\%), and Site 6 was below the optimum for nitrogen. Recommendations for the optimum nitrogen:phosphorus ratio range from 13 to 18 (Herbert 1996; Judd et al., 1996; Schonau 1983). Averaged over all measurement periods, Sites 1, 2 and 4 had nitrogen:phosphorus ratios within this range; however, individual measurement periods were as high 23. Sites 3, 5 and 6 had nitrogen:phosphorus ratios greater than this range.

The production rates reported here are in the range of Eucalyptus growth rates documented in the literature. The volume growth in our study ranged from 50 to $108 \mathrm{~m}^{3} \mathrm{ha}^{-1} \mathrm{yr}^{-1}$ or 23 to $49 \mathrm{Mg} \mathrm{ha}^{-1} \mathrm{yr}^{-1}$ using the wood density data $\left(\sim 2.2 \mathrm{~m}^{3} \mathrm{Mg}^{-1}\right)$ from Smethurst et al. (2003) for conversion. Reported growth rates in Australia are in the same range, i.e., 10 to $30 \mathrm{Mg} \mathrm{ha}^{-1} \mathrm{yr}^{-1}$ for E. nitens (Smethurst et al., 2003) and $274 \mathrm{Mg} \mathrm{ha}^{-1}$ at age nine $\left(\sim 30 \mathrm{Mg} \mathrm{ha}^{-1} \mathrm{yr}^{-1}\right)$ for E. grandis (Birk and Turner 1992). Other reports include 28-42 $\mathrm{Mg} \mathrm{ha}^{-1} \mathrm{yr}^{-1}$ for E. grandis $x$ urophylla clones in Brazil (Stape et al., 2008) and 22-35 Mg ha' ${ }^{1} \mathrm{yr}^{-1}$ for E. grandis in South Africa (Campion et al., 2005). The studies in Brazil and South Africa included an irrigation component and both sites experienced positive volume growth responses to irrigation to produce the high end of the reported ranges. Our sites had similar or better productivity likely due, at least in part, to relatively high ambient rainfall where four sites $(1,2,4$ and 6$)$ received an average of more than $2000 \mathrm{~mm}$ annual precipitation. Site 5 had the lowest productivity (22-27 $\left.\mathrm{Mg} \mathrm{ha}^{-1} \mathrm{yr}^{-1}\right)$ and lowest average rainfall ( $1165 \mathrm{~mm} \mathrm{yr}^{-1}$, i.e., less than half that observed at Sites 2 and 6$)$. In this situation, the primary limiting factor at Site 5 may have been water availability rather than nutrient limitations, which may explain the lack of treatment response at this site. Sites 2, 3 and 6, which were also not responsive to treatment, may have been close to their maximum potential productivity given that control growth at 313 these sites was more than $79 \mathrm{~m}^{3} \mathrm{ha}^{-1} \mathrm{yr}^{-1}$. The treatments may have improved growth but not enough 314 such that a significant improvement could be detected. However, maximum growth rates at Sites 1 and 4 315 were 99 and $108 \mathrm{~m}^{3} \mathrm{ha}^{-1} \mathrm{yr}^{-1}$, respectively, and both reached an asymptote (significant quadratic response), indicating they had reached maximum productivity given their other resources (nutrients, light, 317 water).

All sites had at least one nutrient concentration below optimum, but only two sites had a positive growth response to treatment, which indicated that other factors were limiting (e.g., Site 5), stands were already close to their productive potential (e.g., Sites 2, 3, and 6), not all nutrient limitations were 
addressed with treatment, or the treatments induced other problems that limited growth. Calcium and magnesium were not added although they were considered below optimum for Sites 4 and 1 , respectively. These were the responsive sites; apparently sub-optimal nutrient concentrations may support very good overall growth. For Sites 1, 2, 3, and 4 where nutrient concentration data were available throughout the study, there was no indication that other elements were adversely affected by treatment. Potassium was reduced through time at Sites 1 and 2 but never dropped below the optimum and never dropped as low as the potassium at Site 4 where the highest growth rates were achieved. Other elements fluctuated slightly over time but the absolute value did not change much.

Several conditions observed in this study provide a cautionary note in using foliar nutrient concentrations as the sole guide for determining nutrient limitations: Foliar nutrient concentrations may decrease when nutrients are added, e.g., foliar nitrogen concentrations decreased when nitrogen was added at Site 1. Foliar nutrient concentrations may not change when nutrients identified as limiting are added, e.g., phosphorus at Site 1. Foliar nutrient concentrations could be well below optimal levels and still support high growth rates, e.g., potassium at Site 4. Significant fluctuations in the control plot nutrient concentrations were observed over time, e.g., Site 4 nitrogen, Site 3 potassium. These situations make it difficult to interpret foliar nutrient concentration data with confidence and use them as a management tool. However, the nitrogen limitation at Site 4 was identified by examining the foliar nitrogen concentrations and even though there was fluctuation over time in the control, the treated plots tracked the control but at a higher level (Figure 1A and $1 \mathrm{~B}$ ). Another option to improve utility of the foliar nutrient concentration data is to compare them directly to the growth response data; however, this has met with mixed success; in some studies, foliar nutrient concentrations explained over $70 \%$ of the variation in growth while in other 342 studies, foliar nutrient concentrations were not significant explanatory variables (Judd et al., 1996). Other work found the amount of foliage, estimated as leaf area index, to be a useful tool for predicting growth and potential response to nutrients in Eucalyptus (Campion et al., 2005; Cannell 1989; Landsberg and

345 Sands 2011; Smethurst et al., 2003; Stape et al., 2008).

Our study examined not only whether a site was responsive to nutrient addition but also the 348 additions and these additions can be quite large before the response stops increasing. The two 
349 responsive sites required 360 and $480 \mathrm{~kg}$ nitrogen $\mathrm{ha}^{-1}$ to reach a point where no additional volume 350 response was produced with additional nitrogen. As previously mentioned, growth at this point was quite 351 high; however, it may not have been the maximum productivity possible because another resource may 352 have been limiting at that time. In all but one test, application frequency did not affect response if the 353 cumulative applied dose was equivalent. This information gives confidence that a given dose applied 354 using a range of frequencies will yield the same response and allows managers more flexibility in 355 planning their nutrient applications. Foliar nutrient concentrations are helpful in identifying sites that may 356 respond to fertilization applied at juvenile stages; however, they need to be used with caution. 
357 Figure titles

358 Figure 1. Foliar nitrogen (A), phosphorus (B) and boron (C) concentrations from Sites 4, 4 and 3 , respectively. Asterisks indicate measurement dates when the control treatment was significantly less than at least one of the fertilizer treatments. Treatment codes correspond to treatments listed in Table 3.

362 Figure 2. Three-year volume response versus cumulative applied nitrogen dose at six Eucalyptus grandis sites in Colombia where nitrogen, phosphorus and boron were applied at different rates and frequencies.

Figure 3. Three-year volume response at six Eucalyptus grandis sites in Colombia where a given nitrogen dose was applied at different rates and frequencies of application. $X$ axis labels represent the site-cumulative dose, where site is nominal (1-6) and dose is in $\mathrm{kg}$ elemental nitrogen ha ${ }^{-1}$ applied in 1, 2, 3 or 6 applications. 


\section{Acknowledgements}

372 We appreciate support from Forest Productivity Cooperative members and especially Smurfit Kappa

373 Colombia for their role in the establishment and management of the trials central to this publication. We

374 gratefully acknowledge the support provided by the Department of Forest Resources and Environmental

375 Conservation at Virginia Polytechnic Institute and State University, the Departamento de Silvicultura,

376 Facultad de Ciencias Forestales, Universidad de Concepción and the Department of Forestry and

377 Environmental Resources at North Carolina State University. Funding for this work was provided in part

378 by the Virginia Agricultural Experiment Station and the McIntire-Stennis Program of the National Institute

379 of Food and Agriculture, U.S. Department of Agriculture. The use of trade names in this paper does not

380 imply endorsement by the associated agencies of the products named, nor criticism of similar ones not

381 mentioned. 
Table 1. Site location and soil and geologic characteristics for the six sites in Colombia where Eucalyptus grandis was fertilized at different doses and frequencies.

\begin{tabular}{|c|c|c|c|c|c|c|}
\hline \multirow[b]{2}{*}{ Variable } & \multicolumn{6}{|c|}{ Site } \\
\hline & 1 & 2 & 3 & 4 & 5 & 6 \\
\hline County & Cauca-Cajibio & Valle-Darien & Valle-Darien & Cauca-Meseta & Valle-Cumbre & Cauca-Salinas \\
\hline Nearest town & Popayan & Pereira & Darien & Popayan & Cumbre & Salinas \\
\hline Latitude (decimal degrees) & 2.6 & 4.7 & 4.05 & 2.5 & 3.67 & 2.43 \\
\hline Longitude (decimal degrees) & -76.62 & -75.67 & -76.43 & -73.62 & -76.52 & -76.55 \\
\hline Installation Year & 2000 & 2000 & 2000 & 2003 & 2004 & 2004 \\
\hline Age (months) & 22 & 21 & 24 & 17 & 11 & 14 \\
\hline Previous Land use & Pasture & $\begin{array}{l}\text { E. grandis } \\
\text { Plantation }\end{array}$ & $\begin{array}{l}\text { E. grandis } \\
\text { Plantation }\end{array}$ & $\begin{array}{l}\text { P. oocarpa } \\
\text { plantation }\end{array}$ & $\begin{array}{l}\text { P. maximinoi } \\
\text { plantation }\end{array}$ & $\begin{array}{l}\text { E. grandis } \\
\text { Plantation }\end{array}$ \\
\hline Elevation (masl) & 1774 & 1690 & 1900 & 1730 & 1738 & 2127 \\
\hline Precipitation (mm yr ${ }^{-1}$ ) & 2310 & 2664 & 1602 & 2169 & 1165 & 2591 \\
\hline Mean annual temperature $\left({ }^{\circ} \mathrm{C}\right)$ & 19.3 & 18.3 & 19.9 & 19.3 & 19.9 & 19.3 \\
\hline Soil Series & Pubenza & Santa Rosa & La Cristalina & Pubenza & Carbonero & Salinas \\
\hline Parent material & Volcanic ash & Volcanic ash & Volcanic ash & Volcanic ash & Volcanic ash & Volcanic ash \\
\hline Soil taxonomy & Hapludands & $\begin{array}{c}\text { Acrudoxic } \\
\text { hapludands }\end{array}$ & $\begin{array}{c}\text { Andic } \\
\text { Dystrudepts }\end{array}$ & $\begin{array}{c}\text { Acrudoxic } \\
\text { Hydric } \\
\text { Melanudands }\end{array}$ & $\begin{array}{c}\text { Acrodoxic } \\
\text { hydric } \\
\text { hapludands }\end{array}$ & $\begin{array}{c}\text { Acrudoxic } \\
\text { Melanudands }\end{array}$ \\
\hline Surface texture & Loam & Clay loam & Silty clay loam & Silty loam & Silty loam & Silty loam \\
\hline Drainage & Well drained & Well drained & Well drained & Well drained & $\begin{array}{l}\text { Moderately } \\
\text { well drained }\end{array}$ & Well drained \\
\hline A horizon depth $(\mathrm{cm})$ & 24 & 15 & 13 & 40 & 25 & 35 \\
\hline Bulk density $\left(\mathrm{g} \mathrm{cm}^{-3}\right)$ & 0.49 & 0.69 & 0.56 & 0.51 & 0.51 & 0.71 \\
\hline $\mathrm{pH}$ & 5.4 & 4.8 & 5.3 & 4.7 & 4.8 & 5.3 \\
\hline Organic matter (\%) & 0.58 & 9.2 & 18.2 & 25.6 & 18 & 0.46 \\
\hline Nitrogen (\%) & 15.9 & 0.4 & 0.63 & 0.8 & 0.63 & 11.8 \\
\hline Phosphorus ( $\mathrm{mg} \mathrm{kg}^{-1}$ ) & 3 & 3 & 2 & 0.5 & 1 & 5 \\
\hline Potassium ( $\left.\mathrm{mg} \mathrm{kg}^{-1}\right)$ & 0.07 & 0.16 & 0.17 & 0.09 & 0.12 & 0.34 \\
\hline Calcium (mg kg ${ }^{-1}$ ) & 0 & 0.3 & 0.1 & 0.1 & 2.4 & 2.3 \\
\hline Magnesium (mg kg$\left.{ }^{-1}\right)$ & 0.1 & 0.1 & 0.2 & 0.1 & 0.6 & 0.5 \\
\hline Aluminum (mg kg $\left.{ }^{-1}\right)$ & 0.3 & 0.7 & 1.6 & 1.7 & 0.9 & 0.4 \\
\hline Number of blocks & 3 & 3 & 3 & 4 & 4 & 4 \\
\hline
\end{tabular}


Table 2. Initial stand conditions (prior to fertilization) showing mean and standard error (SE) at the six sites in Colombia where Eucalyptus grandis was fertilized with different frequencies and doses of nutrients.

\begin{tabular}{|c|c|c|c|c|c|c|c|c|c|c|}
\hline \multirow[b]{2}{*}{ Site } & \multicolumn{2}{|c|}{$\begin{array}{c}\text { Diameter at } \\
\text { breast height }\end{array}$} & \multicolumn{2}{|c|}{ Height } & \multicolumn{2}{|c|}{ Basal area } & \multicolumn{2}{|c|}{ Volume } & \multicolumn{2}{|c|}{ Stocking } \\
\hline & $\begin{array}{c}\text { mean } \\
\mathrm{cm}\end{array}$ & SE & $\begin{array}{c}\text { mean } \\
m\end{array}$ & SE & $\begin{array}{c}\text { mean } \\
\mathrm{m}^{2} \mathrm{ha}^{-1}\end{array}$ & SE & $\begin{array}{c}\text { mean } \\
\mathrm{m}^{3} \mathrm{ha}^{-1}\end{array}$ & SE & $\begin{array}{l}\text { mean } \\
\text { trees ha-1 }\end{array}$ & SE \\
\hline 1 & 6.9 & 0.07 & 7.0 & 0.12 & 5.3 & 0.12 & 43.9 & 0.8 & 1280 & 6 \\
\hline 2 & 5.2 & 0.05 & 5.6 & 0.03 & 2.9 & 0.10 & 27.6 & 0.9 & 1147 & 28 \\
\hline 3 & 9.5 & 0.04 & 10.9 & 0.06 & 8.4 & 0.05 & 66.6 & 0.5 & 1129 & 8 \\
\hline 4 & 5.7 & 0.04 & 6.5 & 0.03 & 2.9 & 0.03 & 27.4 & 0.2 & 1119 & 9 \\
\hline 5 & 3.3 & 0.02 & 3.4 & 0.02 & 0.8 & 0.01 & 12.5 & 0.1 & 959 & 4 \\
\hline 6 & 5.1 & 0.05 & 5.0 & 0.03 & 2.2 & 0.04 & 22.3 & 0.2 & 1027 & 4 \\
\hline
\end{tabular}


Table 3. Treatments applied at each of the six sites in Colombia where Eucalyptus grandis was fertilized.

Phosphorus and boron were added at the same time as nitrogen at 0.1 and 0.005 times the nitrogen rate, respectively. An ' $\mathrm{x}$ ' indicates that treatment was applied.

\begin{tabular}{|c|c|c|c|c|c|c|c|c|c|}
\hline \multirow{2}{*}{$\begin{array}{c}\text { Treatment } \\
\text { code }\end{array}$} & \multirow{2}{*}{$\begin{array}{c}\text { Dose of } \\
\text { elemental } \mathrm{N} \\
\text { applied each } \\
\text { time }\left(\mathrm{kg} \mathrm{N} \mathrm{ha}^{-1}\right)\end{array}$} & $\begin{array}{l}\text { Frequency } \\
\text { of application }\end{array}$ & $\begin{array}{c}\text { umulative } \mathrm{N} \text { do } \\
3 \text { years after } \\
\text { initiation }\end{array}$ & & & Stud & & \multirow[b]{2}{*}{5} & \multirow[b]{2}{*}{6} \\
\hline & & (years) & $\left(\mathrm{kg} \mathrm{N} \mathrm{ha}^{-1}\right)$ & 1 & 2 & 3 & 4 & & \\
\hline 0 & 0 & 0 & 0 & $x$ & $x$ & $x$ & $x$ & $x$ & $x$ \\
\hline 506 & 60 & 0.5 & 360 & $x$ & $x$ & $x$ & $x$ & & \\
\hline 509 & 90 & 0.5 & 540 & & & & $x$ & & \\
\hline 512 & 120 & 0.5 & 720 & $x$ & $x$ & $x$ & & & \\
\hline 106 & 60 & 1 & 180 & $x$ & $x$ & $x$ & & & \\
\hline 107 & 75 & 1 & 225 & & & & & $x$ & $x$ \\
\hline 109 & 90 & 1 & 270 & & & & $x$ & $x$ & $x$ \\
\hline 112 & 120 & 1 & 360 & $x$ & $x$ & $x$ & $x$ & $x$ & $x$ \\
\hline 115 & 150 & 1 & 450 & & & & & $x$ & $x$ \\
\hline 118 & 180 & 1 & 540 & & & & $x$ & $x$ & $x$ \\
\hline 124 & 240 & 1 & 720 & $x$ & $x$ & $x$ & & & \\
\hline 212 & 120 & 2 & 240 & & & & $x$ & $x$ & $x$ \\
\hline 218 & 180 & 2 & 360 & & & & $x$ & $x$ & $x$ \\
\hline 224 & 240 & 2 & 480 & $x$ & $x$ & $x$ & $x$ & $x$ & $x$ \\
\hline 225 & 250 & 2 & 500 & & & & & & $x$ \\
\hline 324 & 240 & 3 & 240 & & & & & & $x$ \\
\hline
\end{tabular}


Table 4. Foliar nutrient concentrations for the control treatment (no fertilizer additions) prior to study initiation and every six months thereafter at the six sites in Colombia where fertilizer was applied in Eucalyptus grandis stands. No samples were collected at Sites 5 and 6 after the initial measurement due to limited resources available for sampling. NA indicates data is not available.

\begin{tabular}{|c|c|c|c|c|c|c|c|c|c|c|c|}
\hline Site & $\begin{array}{c}\text { Months since } \\
\text { treatment initiation }\end{array}$ & $\begin{array}{c}\mathrm{N} \\
(\%)\end{array}$ & $\begin{array}{c}P \\
(\%)\end{array}$ & $\begin{array}{c}\mathrm{K} \\
(\%)\end{array}$ & $\begin{array}{l}\mathrm{Ca} \\
(\%)\end{array}$ & $\begin{array}{l}\mathrm{Mg} \\
(\%)\end{array}$ & $\begin{array}{c}S \\
(\%)\end{array}$ & $\begin{array}{c}\text { B } \\
(\mathrm{ppm})\end{array}$ & $\begin{array}{c}\mathrm{Zn} \\
\text { (ppm) }\end{array}$ & $\begin{array}{c}\mathrm{Mn} \\
(\mathrm{ppm})\end{array}$ & $\begin{array}{c}\mathrm{Cu} \\
(\mathrm{ppm})\end{array}$ \\
\hline \multirow[t]{7}{*}{1} & 0 & 2.02 & 0.11 & 1.01 & 1.11 & 0.15 & 0.19 & 10 & 20 & 437 & 8 \\
\hline & 6 & 1.75 & 0.10 & 0.90 & 0.88 & 0.14 & 0.15 & 7 & 17 & 360 & 7 \\
\hline & 12 & 1.55 & 0.11 & 0.92 & 1.12 & 0.15 & 0.17 & 13 & 18 & 488 & 7 \\
\hline & 18 & 1.60 & 0.11 & 0.84 & 0.94 & 0.16 & 0.16 & 14 & 19 & 503 & 6 \\
\hline & 24 & 1.47 & 0.11 & 0.88 & 1.03 & 0.17 & 0.12 & 17 & 14 & 422 & 7 \\
\hline & 30 & 1.91 & 0.11 & 0.84 & 0.77 & 0.22 & 0.16 & 68 & 14 & 316 & 7 \\
\hline & 36 & 1.83 & 0.11 & 0.91 & 0.80 & 0.23 & 0.15 & 53 & 14 & 319 & 8 \\
\hline \multirow[t]{7}{*}{2} & 0 & 2.26 & 0.13 & 1.13 & 1.03 & 0.17 & 0.19 & 21 & 27 & 842 & 10 \\
\hline & 6 & 1.83 & 0.08 & 0.84 & 1.33 & 0.14 & 0.16 & 20 & 22 & 872 & 6 \\
\hline & 12 & 1.67 & 0.10 & 0.84 & 1.31 & 0.17 & 0.18 & 27 & 17 & 1138 & 7 \\
\hline & 18 & 1.71 & 0.09 & 0.90 & 1.40 & 0.19 & 0.16 & 31 & 17 & 1100 & 6 \\
\hline & 24 & 1.66 & 0.10 & 0.83 & 1.04 & 0.21 & 0.15 & 31 & 14 & 941 & 6 \\
\hline & 30 & 1.80 & 0.12 & 0.92 & 0.93 & 0.24 & 0.17 & 33 & 18 & 830 & 7 \\
\hline & 36 & 1.90 & 0.14 & 0.78 & 0.88 & 0.31 & 0.19 & 26 & 19 & 688 & 8 \\
\hline \multirow[t]{7}{*}{3} & 0 & 2.15 & 0.10 & 0.74 & 1.33 & 0.16 & 0.19 & 13 & 20 & 1527 & 7 \\
\hline & 6 & 2.12 & 0.10 & 0.74 & 1.14 & 0.13 & 0.19 & 17 & 17 & 1365 & 5 \\
\hline & 12 & 2.13 & 0.11 & 0.80 & 1.21 & 0.16 & 0.18 & 21 & 21 & 1504 & 6 \\
\hline & 18 & 2.45 & 0.13 & 0.79 & 0.96 & 0.16 & NA & NA & NA & NA & NA \\
\hline & 24 & 2.19 & 0.11 & 0.77 & 0.84 & 0.13 & 0.16 & 19 & 17 & 1330 & 7 \\
\hline & 30 & 2.35 & 0.11 & 0.75 & 0.99 & 0.15 & 0.21 & 29 & 15 & 1667 & 6 \\
\hline & 36 & 2.18 & 0.13 & 0.82 & 0.85 & 0.20 & 0.21 & 19 & 20 & 1353 & 7 \\
\hline \multirow[t]{7}{*}{4} & 0 & 1.73 & 0.09 & 0.49 & 0.72 & 0.23 & 0.15 & 35 & 12 & 688 & 7 \\
\hline & 6 & 1.77 & 0.08 & 0.47 & 0.71 & 0.22 & 0.14 & 51 & 12 & 696 & 7 \\
\hline & 12 & 1.50 & 0.08 & 0.57 & 0.70 & 0.25 & 0.13 & 44 & 11 & 525 & 5 \\
\hline & 18 & 1.19 & 0.07 & 0.54 & 0.60 & 0.23 & 0.13 & 29 & 10 & 444 & 5 \\
\hline & 24 & 1.58 & 0.10 & 0.56 & 0.62 & 0.29 & 0.15 & 23 & 12 & 516 & 5 \\
\hline & 30 & 1.35 & 0.09 & 0.59 & 0.51 & 0.22 & 0.13 & 35 & 14 & 471 & 6 \\
\hline & 36 & 1.77 & 0.11 & 0.66 & 0.60 & 0.29 & 0.18 & 32 & 15 & 498 & 6 \\
\hline 5 & 0 & 2.34 & 0.11 & 0.98 & 1.37 & 0.17 & 0.20 & 23 & 21 & 415 & 8 \\
\hline 6 & 0 & 1.95 & 0.08 & 0.78 & 1.59 & 0.14 & 0.17 & 31 & 15 & 914 & 8 \\
\hline
\end{tabular}


Table 5. Statistical tests ( $p$ values) for treatment, time since treatment initiation and interaction effects on foliar nutrient concentrations for four of the six sites where fertilizer was applied at different rates and frequencies in in Colombia. Tests were not completed on Sites 5 and 6 because foliar collections were only completed prior to treatment initiation at those sites. Values in bold are less than 0.05 .

\begin{tabular}{|c|c|c|c|c|c|c|c|c|c|c|c|}
\hline Site & Effect & $\mathrm{N}$ & $P$ & $\mathrm{~K}$ & $\mathrm{Ca}$ & $\mathrm{Mg}$ & $\mathrm{S}$ & B & $\mathrm{Zn}$ & $\mathrm{Mn}$ & $\mathrm{Cu}$ \\
\hline 1 & Treatment & 0.010 & 0.584 & 0.002 & 0.011 & 0.236 & 0.080 & 0.817 & 0.837 & 0.408 & 0.238 \\
\hline 1 & Time since treatment initiation (TSTI) & 0.000 & 0.072 & 0.000 & 0.000 & 0.000 & 0.000 & 0.000 & 0.000 & 0.000 & 0.002 \\
\hline 1 & Treatment x TSTI & 0.404 & 0.584 & 0.341 & 0.318 & 0.997 & 0.289 & 0.174 & 0.880 & 0.134 & 0.463 \\
\hline 2 & Treatment & 0.271 & 0.122 & 0.009 & 0.185 & 0.000 & 0.662 & 0.359 & 0.076 & 0.123 & 0.082 \\
\hline 2 & Time since treatment initiation (TSTI) & 0.000 & 0.000 & 0.000 & 0.000 & 0.000 & 0.000 & 0.000 & 0.000 & 0.000 & 0.000 \\
\hline 2 & Treatment x TSTI & 0.628 & 0.016 & 0.084 & 0.474 & 0.113 & 0.783 & 0.369 & 0.999 & 0.082 & 0.550 \\
\hline 3 & Treatment & 0.234 & 0.797 & 0.076 & 0.249 & 0.105 & 0.110 & 0.000 & 0.963 & 0.959 & 0.473 \\
\hline 3 & Time since treatment initiation (TSTI) & 0.002 & 0.000 & 0.012 & 0.000 & 0.000 & 0.000 & 0.000 & 0.000 & 0.003 & 0.000 \\
\hline 3 & Treatment $x$ TSTI & 0.806 & 0.498 & 0.917 & 0.600 & 0.808 & 0.982 & 0.004 & 0.772 & 0.884 & 0.741 \\
\hline 4 & Treatment & 0.000 & 0.000 & 0.168 & 0.806 & 0.086 & 0.011 & 0.000 & 0.140 & 0.950 & 0.922 \\
\hline 4 & Time since treatment initiation (TSTI) & 0.000 & 0.000 & 0.000 & 0.000 & 0.000 & 0.000 & 0.000 & 0.000 & 0.000 & 0.000 \\
\hline 4 & Treatment x TSTI & 0.000 & 0.000 & 0.368 & 0.820 & 0.155 & 0.625 & 0.197 & 0.063 & 0.477 & 0.079 \\
\hline
\end{tabular}


Table 6a. Three year survival and growth measurements (treatment mean) and response and percent response relative to the control treatment for three of the six sites in Colombia where Eucalyptus grandis was fertilized.

\begin{tabular}{|c|c|c|c|c|c|c|c|c|c|c|c|c|c|c|c|c|c|c|c|}
\hline \multirow[b]{3}{*}{ Site } & \multirow{3}{*}{$\begin{array}{c}\text { Treatment } \\
\text { code }\end{array}$} & \multicolumn{4}{|c|}{ Diameter } & \multicolumn{4}{|c|}{ Height } & \multicolumn{4}{|c|}{ Basal area } & \multicolumn{4}{|c|}{ Volume } & \multicolumn{2}{|l|}{ Survival } \\
\hline & & \multirow{2}{*}{$\begin{array}{c}\text { Growth } \\
\mathrm{cm}\end{array}$} & \multicolumn{3}{|c|}{ Response } & \multirow{2}{*}{$\begin{array}{c}\text { Growth } \\
\mathrm{m}\end{array}$} & \multicolumn{3}{|c|}{ Response } & \multirow{2}{*}{$\begin{array}{l}\text { Growth } \\
\mathrm{m}^{2} \mathrm{ha}^{-1}\end{array}$} & \multicolumn{3}{|c|}{ Response } & \multirow{2}{*}{$\begin{array}{l}\text { Growth } \\
\mathrm{m}^{3} \mathrm{ha}^{-1}\end{array}$} & & \multicolumn{2}{|c|}{ Response } & \multirow[b]{2}{*}{$\%$} & \\
\hline & & & & $\mathrm{cm}$ & $\%$ & & & $\mathrm{~m}$ & $\%$ & & & $\mathrm{~m}^{2} \mathrm{ha}^{-1}$ & $\%$ & & & $m^{3} h^{-1}$ & $\%$ & & \\
\hline 1 & 0 & 11.8 & $\mathrm{a}$ & & & 16.0 & $\mathrm{a}$ & & & 15.5 & $\mathrm{a}$ & & & 156 & $\mathrm{a}$ & & & 95 & $\mathrm{a}$ \\
\hline 1 & 106 & 13.3 & $a b$ & 1.5 & 13 & 16.6 & $a b$ & 0.6 & 4 & 18.5 & $a b$ & 3.0 & 19 & 196 & $a b$ & 40 & 26 & 92 & a \\
\hline 1 & 112 & 14.0 & $b$ & 2.2 & 19 & 18.7 & $a b$ & 2.7 & 17 & 20.9 & $a b$ & 5.4 & 35 & 225 & $a b$ & 69 & 44 & 96 & a \\
\hline 1 & 124 & 15.4 & $b$ & 3.6 & 30 & 20.7 & $b$ & 4.7 & 29 & 24.8 & $b$ & 9.3 & 60 & 298 & $\mathrm{~b}$ & 142 & 91 & 93 & $\mathrm{a}$ \\
\hline 1 & 224 & 15.1 & $b$ & 3.3 & 28 & 20.8 & $b$ & 4.8 & 30 & 23.8 & $b$ & 8.3 & 54 & 278 & $b$ & 122 & 78 & 92 & a \\
\hline 1 & 506 & 15.0 & $b$ & 3.2 & 28 & 20.3 & $a b$ & 4.3 & 27 & 23.5 & $b$ & 8.0 & 52 & 278 & $b$ & 123 & 79 & 91 & a \\
\hline 1 & 512 & 15.1 & $b$ & 3.3 & 28 & 20.0 & $a b$ & 4.0 & 25 & 24.0 & $b$ & 8.5 & 55 & 279 & $\mathrm{~b}$ & 123 & 79 & 94 & $a$ \\
\hline 2 & 0 & 14.2 & $a$ & & & 19.8 & $a$ & & & 19.4 & $a$ & & & 236 & $a$ & & & 90 & $\bar{a}$ \\
\hline 2 & 106 & 14.0 & $a$ & -0.1 & -1 & 19.2 & a & -0.6 & -3 & 20.7 & $\mathrm{a}$ & 1.3 & 7 & 263 & $a$ & 26 & 11 & 93 & a \\
\hline 2 & 112 & 14.1 & $a$ & -0.1 & 0 & 20.0 & $a$ & 0.2 & 1 & 19.5 & $a$ & 0.0 & 0 & 248 & $a$ & 11 & 5 & 89 & a \\
\hline 2 & 124 & 14.7 & $a$ & 0.6 & 4 & 18.9 & $a$ & -1.0 & -5 & 19.8 & $\mathrm{a}$ & 0.4 & 2 & 252 & $a$ & 16 & 7 & 85 & $a$ \\
\hline 2 & 224 & 14.1 & $a$ & 0.0 & 0 & 18.3 & $\mathrm{a}$ & -1.5 & -8 & 20.6 & $a$ & 1.1 & 6 & 262 & $a$ & 26 & 11 & 92 & $a$ \\
\hline 2 & 506 & 13.3 & $a$ & -0.8 & -6 & 18.5 & $a$ & -1.3 & -7 & 19.9 & $a$ & 0.5 & 3 & 231 & $a$ & -5 & -2 & 100 & a \\
\hline 2 & 512 & 14.1 & $a$ & -0.1 & -1 & 19.7 & $a$ & -0.1 & -1 & 17.2 & $a$ & -2.3 & -12 & 206 & $a$ & -30 & -13 & 82 & $\mathrm{a}$ \\
\hline 3 & 0 & 15.6 & $a$ & & & 22.0 & $a$ & & & 23.0 & $a$ & & & 266 & $a$ & & & 97 & $\mathrm{a}$ \\
\hline 3 & 106 & 15.7 & $a$ & 0.1 & 0 & 21.1 & $\mathrm{a}$ & -0.9 & -4 & 22.4 & $a$ & -0.5 & -2 & 267 & $a$ & 1 & 0 & 94 & a \\
\hline 3 & 112 & 16.0 & a & 0.5 & 3 & 22.0 & $a$ & 0.0 & 0 & 24.5 & $\mathrm{a}$ & 1.6 & 7 & 301 & $a$ & 35 & 13 & 98 & $a$ \\
\hline 3 & 124 & 15.4 & $\mathrm{a}$ & -0.2 & -1 & 21.4 & $a$ & -0.6 & -3 & 20.8 & $a$ & -2.2 & -10 & 248 & $a$ & -18 & -7 & 89 & $a$ \\
\hline 3 & 224 & 15.6 & $a$ & 0.1 & 0 & 21.5 & $\mathrm{a}$ & -0.5 & -2 & 22.9 & a & -0.1 & 0 & 276 & $a$ & 10 & 4 & 94 & a \\
\hline 3 & 506 & 16.1 & $\mathrm{a}$ & 0.5 & 3 & 22.3 & a & 0.3 & 1 & 24.9 & a & 1.9 & 8 & 301 & $a$ & 35 & 13 & 98 & a \\
\hline 3 & 512 & 16.2 & $a$ & 0.6 & 4 & 21.4 & a & -0.6 & -3 & 24.4 & a & 1.5 & 6 & 299 & $a$ & 32 & 12 & 95 & $\mathrm{a}$ \\
\hline
\end{tabular}


Table $6 \mathrm{~b}$. Three year survival and growth measurements (treatment mean) and response and percent response relative to the control treatment for three of the six sites in Colombia where Eucalyptus grandis was fertilized.

\begin{tabular}{|c|c|c|c|c|c|c|c|c|c|c|c|c|c|c|c|c|c|c|c|}
\hline \multirow[b]{3}{*}{ Site } & \multirow{3}{*}{$\begin{array}{l}\text { Treatment } \\
\text { code }\end{array}$} & \multicolumn{4}{|c|}{ Diameter } & & \multicolumn{3}{|c|}{ Height } & \multicolumn{4}{|c|}{ Basal area } & \multicolumn{4}{|c|}{ Volume } & \multirow{2}{*}{\multicolumn{2}{|c|}{ Survival }} \\
\hline & & \multirow{2}{*}{$\begin{array}{c}\text { Growth } \\
\mathrm{cm}\end{array}$} & \multicolumn{3}{|c|}{ Response } & \multirow{2}{*}{$\begin{array}{c}\text { Growth } \\
\mathrm{m}\end{array}$} & \multicolumn{3}{|c|}{ Response } & \multirow{2}{*}{$\begin{array}{l}\text { Growth } \\
\mathrm{m}^{2} \mathrm{ha}^{-1}\end{array}$} & \multicolumn{3}{|c|}{ Response } & \multirow{2}{*}{$\begin{array}{l}\text { Growth } \\
\mathrm{m}^{3} \mathrm{ha}^{-1}\end{array}$} & \multicolumn{3}{|c|}{ Response } & & \\
\hline & & & & $\mathrm{cm}$ & $\%$ & & & $\mathrm{~m}$ & $\%$ & & & $m^{2} h a^{-1}$ & $\%$ & & & $m^{3} \mathrm{ha}^{-1}$ & $\%$ & $\%$ & \\
\hline 4 & 0 & 15.4 & $a$ & & & 21.8 & $a$ & & & 20.9 & $a$ & & & 208 & $a$ & & & 98 & $\mathrm{a}$ \\
\hline 4 & 109 & 17.0 & $\mathrm{~b}$ & 1.6 & 10 & 24.2 & $a b$ & 2.4 & 11 & 25.6 & $b$ & 4.7 & 22 & 281 & $\mathrm{~b}$ & 73 & 35 & 98 & $\mathrm{a}$ \\
\hline 4 & 112 & 17.5 & $\mathrm{~b}$ & 2.1 & 13 & 25.1 & $\mathrm{~b}$ & 3.3 & 15 & 27.0 & $\mathrm{~b}$ & 6.1 & 29 & 301 & $\mathrm{~b}$ & 93 & 45 & 99 & a \\
\hline 4 & 118 & 17.5 & $\mathrm{~b}$ & 2.1 & 14 & 25.1 & $b$ & 3.3 & 15 & 28.8 & $b$ & 7.9 & 38 & 324 & $\mathrm{~b}$ & 116 & 56 & 100 & $\mathrm{a}$ \\
\hline 4 & 212 & 17.2 & $b$ & 1.7 & 11 & 23.7 & $a b$ & 1.9 & 9 & 26.0 & $b$ & 5.1 & 24 & 286 & $\mathrm{~b}$ & 79 & 38 & 99 & a \\
\hline 4 & 218 & 17.5 & $\mathrm{~b}$ & 2.0 & 13 & 25.3 & $\mathrm{~b}$ & 3.5 & 16 & 27.1 & $\mathrm{~b}$ & 6.2 & 30 & 304 & $\mathrm{~b}$ & 96 & 46 & 100 & $a$ \\
\hline 4 & 224 & 17.4 & $b$ & 2.0 & 13 & 24.6 & $a b$ & 2.8 & 13 & 26.9 & $b$ & 6.0 & 29 & 302 & $b$ & 94 & 45 & 99 & $\mathrm{a}$ \\
\hline 4 & 506 & 17.3 & $\mathrm{~b}$ & 1.9 & 12 & 25.3 & $\mathrm{~b}$ & 3.5 & 16 & 26.2 & b & 5.2 & 25 & 290 & $\mathrm{~b}$ & 82 & 39 & 98 & $a$ \\
\hline 4 & 509 & 16.7 & $b$ & 1.2 & 8 & 23.9 & $a b$ & 2.1 & 10 & 25.5 & $b$ & 4.5 & 22 & 280 & $\mathrm{~b}$ & 72 & 35 & 100 & $a$ \\
\hline 5 & 0 & 15.0 & $a$ & & & 18.3 & $a$ & & & 15.6 & $a$ & & & 160 & $\mathrm{a}$ & & & 100 & $a$ \\
\hline 5 & 107 & 15.2 & $a$ & 0.2 & 1 & 18.6 & $a$ & 0.3 & 2 & 14.9 & $a$ & -0.7 & -5 & 157 & $a$ & -3 & -2 & 98 & $a$ \\
\hline 5 & 109 & 15.5 & $a$ & 0.5 & 3 & 18.6 & $a$ & 0.3 & 1 & 16.9 & $a$ & 1.3 & 8 & 180 & $a$ & 20 & 12 & 100 & $a$ \\
\hline 5 & 112 & 14.6 & $\mathrm{a}$ & -0.4 & -3 & 18.0 & $\mathrm{a}$ & -0.3 & -2 & 15.3 & $a$ & -0.3 & -2 & 156 & $a$ & -4 & -3 & 100 & $a$ \\
\hline 5 & 115 & 15.6 & $\mathrm{a}$ & 0.6 & 4 & 18.9 & a & 0.6 & 3 & 16.4 & a & 0.8 & 5 & 177 & $a$ & 17 & 10 & 99 & $a$ \\
\hline 5 & 118 & 15.0 & $a$ & 0.0 & 0 & 18.5 & $a$ & 0.1 & 1 & 14.8 & $a$ & -0.8 & -5 & 153 & $a$ & -7 & -5 & 100 & a \\
\hline 5 & 212 & 14.6 & $a$ & -0.4 & -3 & 18.4 & a & 0.1 & 0 & 14.7 & a & -0.9 & -6 & 149 & $a$ & -11 & -7 & 99 & a \\
\hline 5 & 218 & 14.9 & $a$ & -0.1 & -1 & 18.2 & $a$ & -0.2 & -1 & 15.3 & $a$ & -0.3 & -2 & 156 & $a$ & -4 & -2 & 100 & $a$ \\
\hline 5 & 224 & 14.9 & $\mathrm{a}$ & -0.1 & -1 & 17.8 & a & -0.5 & -3 & 16.0 & a & 0.4 & 2 & 167 & $a$ & 7 & 4 & 100 & $\mathrm{a}$ \\
\hline 6 & 0 & 16.6 & $\mathrm{a}$ & & & 19.8 & $a b$ & & & 22.2 & $a$ & & & 250 & $a$ & & & 100 & $\mathrm{a}$ \\
\hline 6 & 107 & 16.5 & $\mathrm{a}$ & -0.1 & 0 & 19.1 & $\mathrm{a}$ & -0.7 & -4 & 21.7 & $a$ & -0.5 & -2 & 245 & $a$ & -4 & -2 & 100 & $a$ \\
\hline 6 & 109 & 17.3 & $\mathrm{a}$ & 0.7 & 4 & 19.7 & $a b$ & -0.1 & -1 & 23.0 & a & 0.8 & 4 & 267 & $a$ & 17 & 7 & 98 & $a$ \\
\hline 6 & 112 & 16.8 & $\mathrm{a}$ & 0.2 & 1 & 20.2 & $a b$ & 0.4 & 2 & 22.9 & $a$ & 0.7 & 3 & 262 & $a$ & 12 & 5 & 100 & $a$ \\
\hline 6 & 115 & 16.7 & $a$ & 0.1 & 1 & 20.2 & $a b$ & 0.3 & 2 & 21.8 & a & -0.4 & -2 & 250 & $a$ & 0 & 0 & 100 & $a$ \\
\hline 6 & 118 & 16.6 & $a$ & 0.0 & 0 & 20.1 & $a b$ & 0.2 & 1 & 22.2 & $a$ & 0.1 & 0 & 250 & $a$ & 0 & 0 & 100 & $a$ \\
\hline 6 & 212 & 16.4 & $a$ & -0.2 & -1 & 20.7 & $\mathrm{~b}$ & 0.8 & 4 & 21.4 & $a$ & -0.7 & -3 & 236 & $a$ & -14 & -6 & 100 & $a$ \\
\hline 6 & 218 & 17.2 & $\mathrm{a}$ & 0.6 & 3 & 20.2 & $a b$ & 0.4 & 2 & 23.2 & a & 1.1 & 5 & 267 & $a$ & 17 & 7 & 100 & $\mathrm{a}$ \\
\hline 6 & 224 & 17.3 & $a$ & 0.8 & 5 & 20.2 & $a b$ & 0.3 & 2 & 22.6 & $a$ & 0.4 & 2 & 266 & $a$ & 16 & 6 & 98 & $a$ \\
\hline 6 & 225 & 16.8 & $a$ & 0.3 & 2 & 20.0 & $a b$ & 0.1 & 1 & 22.0 & a & -0.1 & -1 & 250 & $a$ & 0 & 0 & 100 & $a$ \\
\hline 6 & 324 & 17.2 & $a$ & 0.7 & 4 & 20.5 & $a b$ & 0.6 & 3 & 22.7 & $a$ & 0.5 & 2 & 262 & $a$ & 12 & 5 & 100 & $a$ \\
\hline
\end{tabular}


Table 7. Summary of statistical significance ( $p$ values) for diameter, height, basal area, volume increments and survival three years after study initiation for

the six sites in Colombia where Eucalyptus grandis was fertilized. Linear and

quadratic effects determine the form of the rate effect (linear or quadratic). Values in bold are less than

\begin{tabular}{cccccc}
0.05. & \multicolumn{5}{c}{ Basal Area } \\
\hline Site & Diameter & Height & Volume & Survival \\
\hline \multicolumn{5}{c}{ Linear effects } \\
\hline 2 & $\mathbf{0 . 0 0 1}$ & $\mathbf{0 . 0 0 9}$ & $\mathbf{0 . 0 0 1}$ & $\mathbf{0 . 0 0 4}$ & 0.304 \\
3 & 0.388 & 0.421 & 0.478 & 0.495 & 0.121 \\
4 & 0.664 & 0.501 & 0.416 & 0.344 & 0.479 \\
5 & $\mathbf{0 . 0 0 0}$ & $\mathbf{0 . 0 0 1}$ & $\mathbf{0 . 0 0 0}$ & $\mathbf{0 . 0 0 0}$ & 0.842 \\
6 & 0.741 & 0.735 & 0.723 & 0.720 & 0.938 \\
& 0.865 & 0.999 & 0.678 & 0.457 & 0.909 \\
\hline 1 & & Quadratic effects & \\
2 & $\mathbf{0 . 0 2 0}$ & 0.080 & $\mathbf{0 . 0 4 7}$ & 0.091 & 0.356 \\
3 & 0.282 & 0.510 & 0.322 & 0.378 & 0.055 \\
4 & 0.647 & 0.384 & 0.369 & 0.347 & 0.386 \\
5 & $\mathbf{0 . 0 0 0}$ & $\mathbf{0 . 0 1 2}$ & $\mathbf{0 . 0 1 3}$ & $\mathbf{0 . 0 0 3}$ & 0.334 \\
6 & 0.683 & 0.645 & 0.717 & 0.779 & 0.956 \\
\hline
\end{tabular}


Table 8. Contrasts ( $p$ values) where the same cumulative dose was applied using different frequencies and doses at the six sites in Colombia where fertilizer was applied in Eucalyptus grandis stands. NT indicates the specified contrast was not tested for this site. Values in bold are less than 0.05 .

\begin{tabular}{|c|c|c|c|c|c|c|}
\hline \multirow[t]{2}{*}{ Site } & \multicolumn{6}{|c|}{ Cumulative Dose (kg N ha } \\
\hline & 360 & 720 & 360 & 540 & 360 & 240 \\
\hline & \multicolumn{6}{|c|}{ Frequencies and doses compared } \\
\hline & 3 doses of 120 & 3 doses of 240 & 3 doses of 120 & 3 doses of 180 & 3 doses of 120 & 2 doses of 120 \\
\hline & 6 doses of 60 & 6 doses of 120 & 2 doses of 180 & 6 doses of 90 & 2 doses of 180 & 1 dose of 240 \\
\hline \multicolumn{7}{|c|}{6 doses of 60} \\
\hline & \multicolumn{6}{|c|}{ Treatments compared } \\
\hline & 112 vs 506 & 124 vs 512 & 112 vs 218 vs 506 & 118 vs 509 & 112 vs 218 & 212 vs 324 \\
\hline 1 & 0.089 & 0.548 & NT & NT & NT & NT \\
\hline 2 & 0.434 & 0.100 & NT & NT & NT & NT \\
\hline 3 & 0.936 & 0.223 & NT & NT & NT & NT \\
\hline 4 & NT & NT & 0.825 & 0.023 & NT & NT \\
\hline 5 & NT & NT & NT & NT & 0.746 & NT \\
\hline 6 & NT & NT & NT & NT & 0.649 & 0.110 \\
\hline
\end{tabular}




\section{References}

Adams, P.R., C.L. Beadle, N.J. Mendham and P.J. Smethurst. 2003. The impact of timing and duration of grass control on growth of a young Eucalyptus globulus Labill. plantation. New Forests, 26 (2): 147-165.

Bennett, L.T., C.J. Weston and P.M. Attiwill. 1997. Biomass, nutrient content and growth response to fertilisers of six-year-old Eucalyptus globulus planatations at three contrasting sites in Gippsland, Victoria. Aust. J. Bot., 45 (1): 103-121.

Birk, E.M. and J. Turner. 1992. Response of flooded gum (E. grandis) to intensive cultural treatments: biomass and nutrient content of eucalypt plantations and native forests. For.Ecol.Manage., 47: 1-28.

Boyd, E. 1998. A compilation of forest plantations statistics for selected African and Latin American countries. Oxford Forestry Institute: London.

Bray, R.H. and L.T. Kurtz. 1945. Determination of total, organic and available forms of phosphorus in soils. Soil Sci., 59: 39-45.

Campion, J.M., L.J. Esprey and M.C. Scholes. 2005. Application of the 3-PG model to a Eucalyptus grandis stand subject to varying levels of water and nutritional constraints in KwaZulu-Natal, South Africa. Southern African Forestry Journal, 203: 3-13.

Campion, J.M., M. Nkosana and M.C. Scholes. 2006. Biomass and N and P pools in above- and belowground components of an irrigated and fertilised Eucalyptus grandis stand in South Africa. Aust.For., 69 (1): $48-57$.

Cannell, M.G.R. 1989. Physiological basis of wood production: a review. Scand.J.For.Res., 4: 459-490.

Cromer, R.N., D.A. Cameron, S.J. Rance, P.A. Ryan and M. Brown. 1993. Response to nutrients in Eucalyptus grandis. 1. Biomass accumulation. For.Ecol.Manage., 62: 211-230.

Da Silva, H.D., C.A. Ferreira and A.F.J. Bellote. 2001. Quantification of the biomass in the trunk of Eucalyptus grandis at different ages. In Rehabilitation of degraded tropical forest ecosystems: Workshop proceedings 2-4 November 1999, Bogor, Indonesia. S. Kobayashi, J.W. Turnbull, T. Toma, T. Mori and N.M.N.A. Majid (eds.), CIFOR, pp. 164-171.

Dell, B. 1996. Diagnosis of nutrient deficiencies in eucalypts. In Nutrition of Eucalyptus. P.M. Attiwill and M.A. Adams (eds.), CSIRO, Collingwood, pp. 417-440.

Dell, B. and N. Malajczuk. 1994. Boron deficiency in eucalypt plantations in China. Can.J.For.Res., 24: 2409-2416.

Dye, P.J. 1996. Response of Eucalyptus grandis trees to soil water deficits. Tree Physiol., 16: 233-238.

FAO. 2010. Global forest resources assessment 2010. FAO Forestry Paper 163. Rome, p. 378.

FAO. 2015. Planted forests in Colombia. http://www.fao.org/forestry/country/18316/en/col/. 
Goncalves, J.L., C.A. Alvares, A.R. Higa, L.D. Silva, A.C. Alfenas, J. Stahl, S.F. Ferraz, W.P. Lima, P.H. Brancalion, A. Hubner, J.P. Bouillet, J.P. Laclau, Y. Nouvellon and D. Epron. 2013. Integrating genetic and silvicultural strategies to minimize abiotic and biotic constraints in Brazilian eucalypt plantations. For.Ecol.Manage., 301: 6-27.

Goncalves, J.L., J.L. Gava and M.C.P. Wichert. 2004. Sustainability of wood production in eucalypt plantations of Brazil. In Site management and productivity in tropical plantation forrests: Proceedings of workshops in Congo July 2001 and China February 2003. E.K.S. Nambiar, J. Ranger, A.E. Tiarks and T. Toma (eds.), CIFOR, Bogor, Indonesia, pp. 3-14.

Goncalves, J.L., J.L. Stape, J.P. Laclau, P.J. Smethurst and J.L. Gava. 2004. Silvicultural effects on the productivity and wood quality of eucalypt plantations. For.Ecol.Manage., 193 (1-2): 45-61.

Herbert, M.A. 1983. The response of Eucalyptus grandis to fertilising with nitrogen, phosphorus, potassium and dolomitic lime on a Mispah soil series. South African Forestry Journal, 124: 4-12.

Herbert, M.A. 1990. Fertilizer/site interactions on the growth and foliar nutrient levels of Eucalyptus grandis. For.Ecol.Manage., 30: 247-257.

Herbert, M.A. 1996. Fertilizers and Eucalypt plantations in South Africa. In Nutrition of Eucalypts. P.M. Attiwill and M.A. Adams (eds.), CSIRO, Collingwood, pp. 303-325.

Hitchcock, D.I. and R.C. Belden. 1933. An accurate semimicro-Kjeldahl method. Ind. Eng. Chem. Anal. Ed., 5 (6): 402-402.

Huang, C.L. and E.E. Schulte. 1985. Digestion of plant tissue for analysis by ICP emission spectroscopy. Commun.Soil Sci.Plant Anal., 16 (9): 943-958.

Judd, T.S. 1996. Simulated nutrient losses due to timber harvesting in highly productive eucalypt forests and plantations. In Nutrition of eucalypts. P.M. Attiwill and M.A. Adams (eds.), CSIRO, Collingwood, pp. 249-258.

Judd, T.S., P.M. Attiwill and M.A. Adams. 1996. Nutrient concentrations in Eucalyptus: A synthesis in relation to differences between taxa, sites and components. In Nutrition of eucalyptus. P.M. Attiwill and M.A. Adams (eds.), CSIRO, Collingwood, pp. 123-153.

Kimmins, J.P. 1997. Biogeochemistry, cycling of nutrients in ecosystems. In Forest ecology, a foundation for sustainable management. J.P. Kimmins (ed.). 2nd Ed., Prentice Hall, Saddle River, N.J., pp. 71-129.

Knecht, M.F. and A. Göransson. 2004. Terrestrial plants require nutrients in similar proportions. Tree Physiol., 24: 447-460.

Landsberg, J.J. and P.J. Sands. 2011. Physiological ecology of forest production Principles, processes and models. Academic Press: London.

Linder, S. 1995. Foliar analysis for detecting and correcting nutrient imbalances in Norway spruce. Ecological Bulletins, 44: 178-190.

Little, K.M. and C.A. Rolando. 2002. Post-establishment vegetation control in a Eucalyptus grandis $x$ E. camaldulensis stand. South African Forestry Journal, 193: 77-80.

Miller, H.G. 1981. Forest Fertilization: Some Guiding Concepts. Forestry, 54 (2): 157-167. 
Myers, B.J., S. Theiveyanathan, N.D. O'Brien and W.J. Bond. 1996. Growth and water use of Eucalyptus grandis and Pinus radiata plantations irrigated with effluent. Tree Physiol., 16: 211-219.

Nzila, J.D., P. Deleporte, J.P. Bouillet, J.P. Laclau and J. Ranger. 2004. Effects of slash management on tree growth and nutrient cycling in second-rotation Eucalyptus replanted sites in the Congo. In Site management and productivity in tropical plantation forests: Proceedings of workshops in Congo July 2001 and China February 2003. E.K.S. Nambiar, J. Ranger, A.E. Tiarks and T. Toma (eds.), CIFOR, Bogor, Indonesia, pp. 15-30.

Prado, J.S. and J. Toro. 1996. Silviculture of eucalypt plantations in Chile. In Nutrition of Eucalypts. P.M. Attiwill and M.A. Adams (eds.), CSIRO, Collingwood, pp. 357-370.

Schonau, A.P.G. 1983. Fertilisation in South African Forestry. South African Forestry Journal, 125 (1-19).

Schonau, A.P.G. and M.A. Herbert. 1989. Fertilizing eucalypts at plantation establishment. For.Ecol.Manage., 29: 221-244.

Shorrocks, V.M. 1997. The occurrence and correction of boron deficiency. Plant and Soil, 193 (1-2): 121148.

Smethurst, P.J., C. Baillie, M. Cherry and G. Holz. 2003. Fertilizer effects on LAI and growth of four Eucalyptus nitens plantations. For.Ecol.Manage., 176 (1-3): 531-542.

Stape, J.L., D. Binkley and M.G. Ryan. 2004. Eucalyptus production and the supply, use and efficiency of use of water, light and nitrogen across a geographic gradient in Brazil. For.Ecol.Manage., 193 (1-2): 1731.

Stape, J.L., D. Binkley and M.G. Ryan. 2008. Production and carbon allocation in a clonal Eucalyptus plantation with water and nutrient manipulations. For.Ecol.Manage., 255: 920-930.

Stape, J.L., D. Binkley, M.G. Ryan, S. Fonseca, R.A. Loos, E.N. Takahashi, C.R. Silva, S.R. Silva, R.E. Hakamada, J.M.A. Ferreira, A.M.N. Lima, J.L. Gava, F.P. Leite, H.B. Andrade, J.M. Alves, G.G.C. Silva and M.R. Azevedo. 2010. The Brazilian Eucalyptus Potential Productivity Project: Influence of water, nutrients and stand uniformity on wood production. For.Ecol.Manage., 259: 1684-1694.

Stone, E.L. 1990. Boron deficiency and excess in forest trees: A review. For.Ecol.Manage., 37: 49-75.

Tamm, C.O. 1964. Determination of nutrient requirements of forest stands. Int.Rev.Forest Research, 1: 115-170.

Turner, J. and M.J. Lambert. 1996. Nutrient cycling and forest management. In Nutrition of eucalypts. P.M. Attiwill and M.A. Adams (eds.), CSIRO, Collingwood, pp. 229-248.

Walkley, A. 1947. A critical examination of a rapid method for determining organic carbon in soils - effect of variations in digestion conditions and of inorganic soil constituents. Soil Science, 63 (4): 251-264.

Whitehurst, G.B. and B.M. Whitehurst. 2004. Volatility-inhibited urea fertilizers. C05C 9/00 (20060101) Ed., Whitehurst Associates,Inc., New Bern, NC.

Whitesell, C.D., D.S. De Bell, T.H. Schubert, R.F. Strand and T.B. Crabb. 1992. Short-rotation management of Eucalyptus: Guidelines for plantations in Hawaii. General Technical Report PSW-GTR137, P.S.R. Station. Albany, California, p. 30. 
Yuan, T.L. and J.G.A. Fiskell. 1959. Aluminum determination, aluminum studies: Soil and plant analysis of aluminum by modification ot hte aluminon method. J.Agric. Food Chem., 7 (2): 115-117.

Zerpa, J.L. and T.R. Fox. 2011. Controls of volatile ammonia losses from loblolly pine plantations fertilized with urea in the southeast USA. Soil Sci.Soc.Am.J., 75 (1): 257-266. 


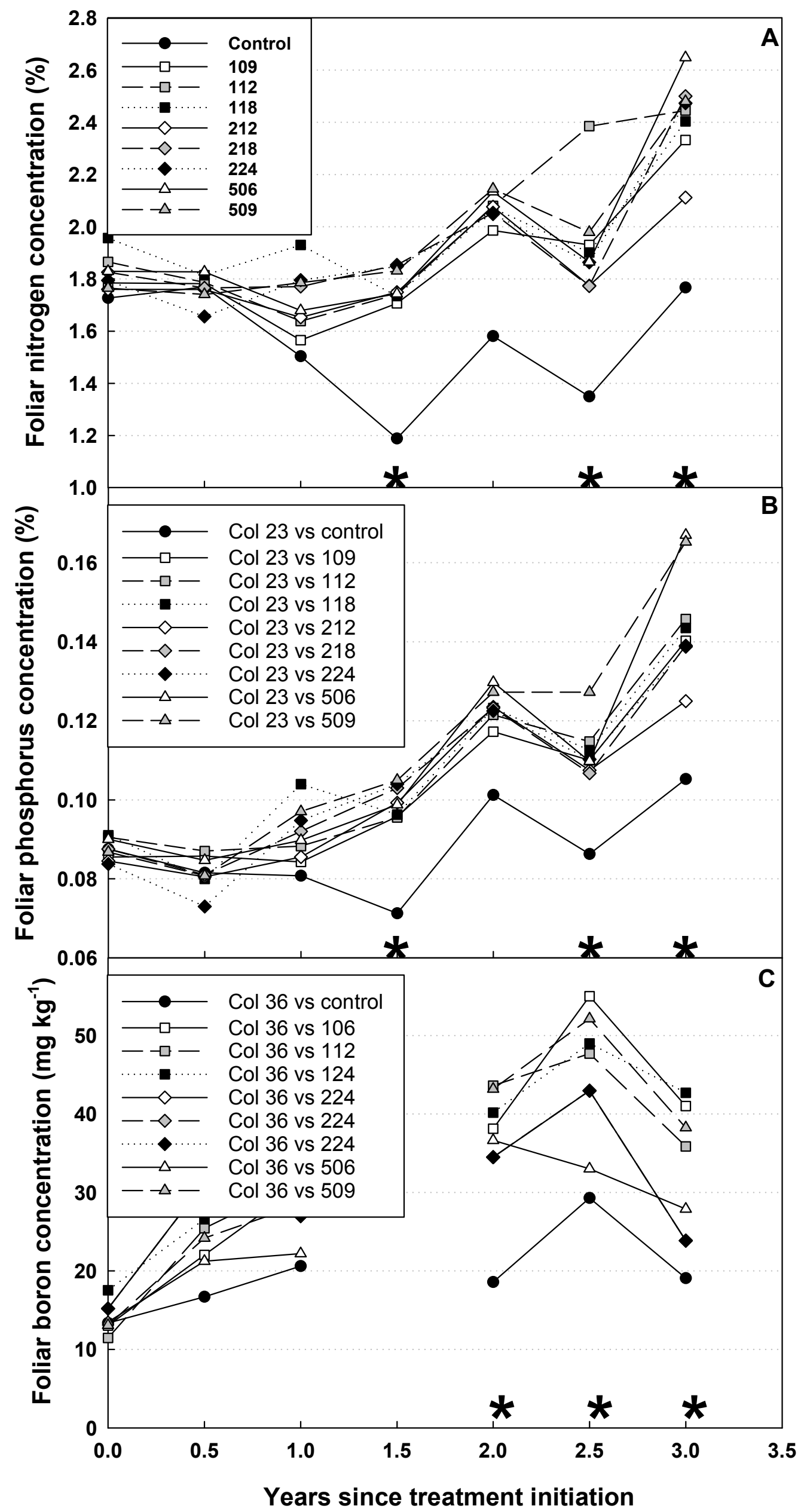

Figure 1. 


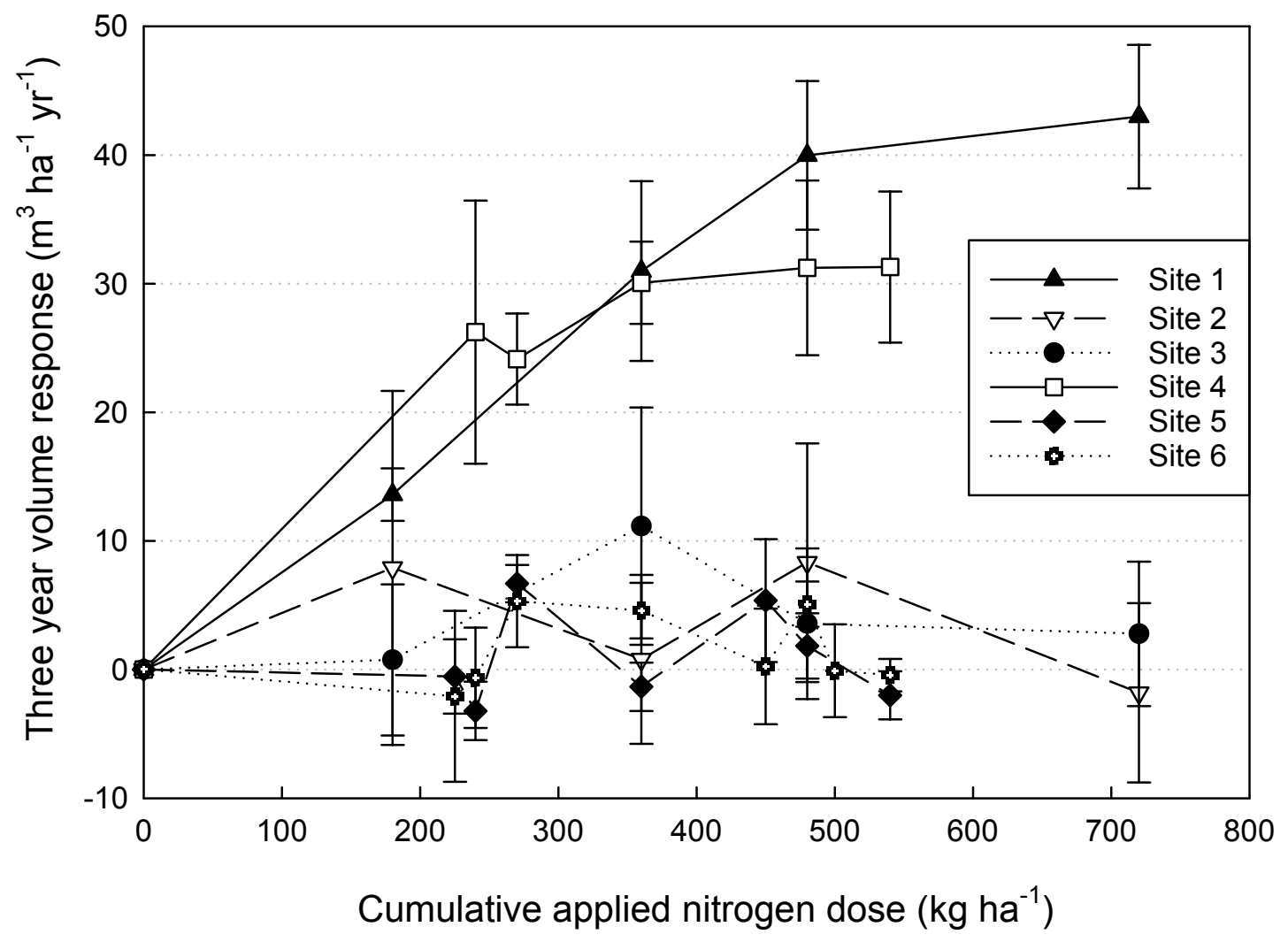

Figure 2. 


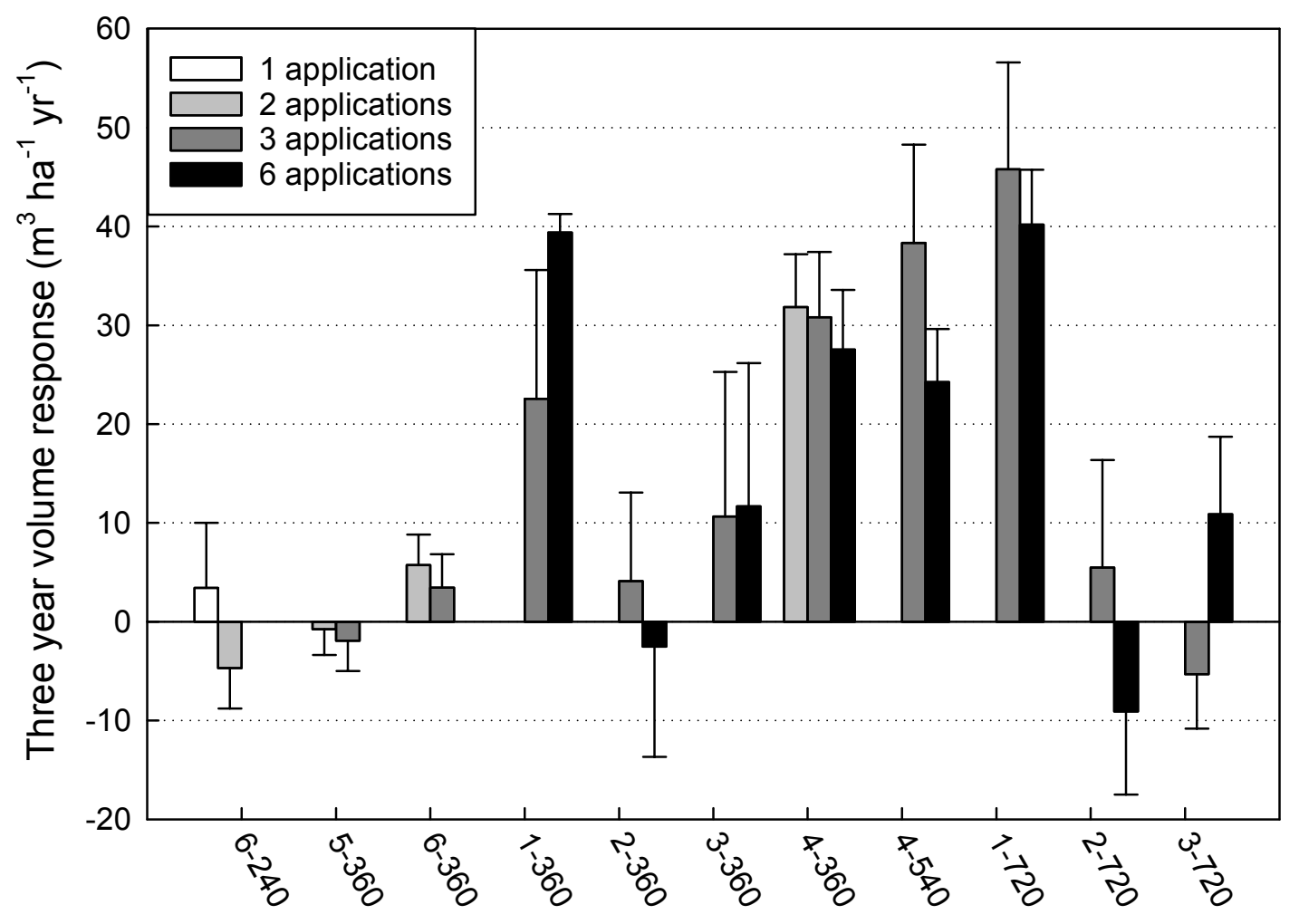

Site - Cumulative nitrogen dose $\left(\mathrm{kg} \mathrm{ha}^{-1}\right)$

Figure 3. 